\title{
Maternal Thyroid Dysfunction, Intrauterine and Fetal Growth Restriction
}

\author{
Ahmed RG* \\ Zoology Department, Beni-Suef University, Egypt
}

Submission: February 27, 2018; Published: April 30, 2018

"Corresponding author: Ahmed RG, Division of Anatomy and Embryology, Zoology Department, Faculty of Science, Beni-Suef University, Beni-Suef, Egypt, Tel: 002-010-91471828 ; Email: ahmedragab08@gmail.com

\section{Letter to Editor}

The bioavailability of maternal thyroid hormones (THs) during pregnancy is critical for the development and growth of fetus and neonates [1-58]. During the second half of gestation, thyroxine (T4) and 3, 5, 3'-triiodothyronine (T3) induce intrauterine growth through increase the fetal anabolic state/ metabolic state and the positive action on the growth regulatory factors and other endocrine systems [59-60]. In late gestation period, the prepartum elevation in the bioavailability of T3 can mediate the maturational actions of the glucocorticoids and increase the functionality of the sympathetic nervous system [60-62]. In turn, this mediation can protect the neonate from the stress of delivery and from the new extrauterine environment [60].

On the other hand, intrauterine growth restriction or fetal growth restriction, a heterogeneous syndrome, means a fetus that cannot reach its growth potential [63-65]. These defects, impair fetal growth and compromises the neonatal adaptation to extrauterine life, can be attributed to the deficiency of THs during intrauterine development [66-68]. These data are reinforced by the results of fetal growth restriction in human and experimental animals (undernutrition and placental insufficiency) [69-72]. Also, hypothyroidism in sheep, goats, horses, and pigs induces the fetal growth restriction $[60,73,74]$. In epidemiological studies, the presence of anti thyroid antibodies (ATA) can increase the risk of intrauterine growth restriction or small for gestational age (SGA; infants are smaller in size and weight than normal) $[65,75,76]$. More interestingly, the risks of birth hypoxia, perinatal death, neonatal obstacles, neurodevelopmental and metabolic syndromes during adult life such as hypertension, type 2 diabetes, and coronary heart disease were increased during intrauterine and fetal growth restriction [77-81]. Indeed, intrauterine growth restriction is related to the gestational hypertensive disorders, under nutrition, infection, smoking, and unexplained factors [82]. Sharma [83] reported that intrauterine growth restriction is a main and silent cause of fetal and neonatal morbidity and mortality.

\section{Conclusion}

In conclusion, it is also worth stating that THs promote the general body growth and the development of fetal individual tissues and organs. In addition, any disorders in the levels of THs during intrauterine development may cause intrauterine and fetal growth restriction. These disorders may disrupt the development and growth of fetus and neonates, and cause several lifelong consequences through permanent fluctuations in most biological systems. Thus, monitoring the activity of maternal THs may prevent any undesirable pathological state during intrauterine development. Additional studies should evaluate the relation between the maternal thyroid disorders, thyroid auto antibodies, intrauterine and fetal growth restriction [84-89].

\section{Conflict of Interest}

The author declares that no competing financial interests exist.

\section{References}

1. Ahmed OM, El Gareib AW, El bakry AM, Abd El Tawab SM, Ahmed RG (2008) Thyroid hormones states and brain development interactions. Int J Dev Neurosci 26(2): 147-209.

2. Ahmed RG (2011) Perinatal 2, 3, 7, 8-tetrachlorodibenzo-p-dioxin exposure alters developmental neuroendocrine system. Food Chem Toxicology 49(6): 1276-1284.

3. Ahmed RG (2012a) Maternal-newborn thyroid dysfunction. In the Developmental Neuro endocrinology, Germany: LAP LAMBERT Academic Publishing GmbH \& Co KG, pp. 1-369.

4. Ahmed RG (2012b) Maternal-fetal thyroid interactions, Thyroid Hormone, Dr. N.K. Agrawal (Ed.), ISBN: 978-953-51-0678-4, In Tech Open Access Publisher, Chapter 5, pp. 125-156.

5. Ahmed R G (2013) Early weaning PCB 95 exposure alters the neonatal endocrine system: thyroid adipokine dysfunction. J Endocrinol 219 (3): 205-215.

6. Ahmed RG (2014) Editorial: Do PCBs modify the thyroid-adipokine axis during development? Annals Thyroid Res 1(1): 12-12.

7. Ahmed RG (2015a) Chapter 1: Hypothyroidism and brain development. In advances in hypothyroidism treatment. Avid Science Borsigstr 9, 10115 Berlin, Germany Avid Science Publications level 6, Melange Towers, Wing a, Hitech City, Hyderabad, Telangana, India, p. 1-40.

8. Ahmed RG (2015b) Hypothyroidism and brain developmental players. Thyroid Research J 8(2): 1-12

9. Ahmed RG (2015c) Editorials and Commentary: Maternofetal thyroid action and brain development. J of Advances in Biology 7(1): 12071213. 
10. Ahmed RG (2016a) Gestational dexamethasone alters fetal neuroendocrine axis. Toxicol Lett 258, 46-54.

11. Ahmed RG (2016b) Neonatal polychlorinated biphenyls-induced endocrine dysfunction. Annals Thyroid Res 2(1): 34-35.

12. Ahmed RG (2016c) Maternal iodine deficiency and brain disorders. Endocrinol Metab Syndr 5: 223.

13. Ahmed RG (2016d) Maternal bisphenol A alters fetal endocrine system: Thyroid adipokine dysfunction. Food Chem Toxico 95: 168-174.

14. Ahmed RG(2017a) Developmental thyroid diseases and GABAergic dysfunction. EC Neurology 8.1: 02-04.

15. Ahmed RG (2017b) Hyperthyroidism and developmental dysfunction. Arch Med 9: 4.

16. Ahmed RG (2017c) Anti-thyroid drugs may be at higher risk for perinatal thyroid disease. EC Pharmacology and Toxicology 4.4: 140142.

17. Ahmed RG (2017d) Perinatal hypothyroidism and cytoskeleton dysfunction. Endocrinol Metab Syndr 6: 271.

18. Ahmed RG(2017e) Developmental thyroid diseases and monoaminergic dysfunction. Advances in Applied Science Research 8(3): 01-10.

19. Ahmed R G (2017f) Hypothyroidism and brain development. J Anim Res Nutr 2(2): 13

20. Ahmed RG (2017g) Antiepileptic drugs and developmental neuroendocrine dysfunction: Every why has A Wherefore? Arch Med $9(6): 2$.

21. Ahmed RG (2017h) Gestational prooxidant-antioxidant imbalance may be at higher risk for postpartum thyroid disease. Endocrinol Metab Syndr 6: 279 .

22. Ahmed RG (2017i) Synergistic actions of thyroid-adipokines axis during development. Endocrinol Metab Syndr 6: 280.

23. Ahmed RG (2017j) Thyroid-insulin dysfunction during development International Journal of Research Studies in Zoology 3(4): 73-75.

24. Ahmed RG (2017k) Developmental thyroid diseases and cholinergic imbalance. International Journal of Research Studies in Zoology 3(4): $70-72$.

25. Ahmed RG (2017l) Thyroid diseases and developmental adenosinergic imbalance. Int J Clin Endocrinol 1(2): 053-055.

26. Ahmed R G (2017m) Maternal anticancer drugs and fetal neuroendocrine dysfunction in experimental animals. Endocrinol Metab Syndr 6: 281

27. Ahmed RG (2017n) Letter: Gestational dexamethasone may be at higher risk for thyroid disease developing peripartum. Open Journal of Biomedical \& Life Sciences (Ojbili) 3(2):01-06.

28. Ahmed RG (2017o) Deiodinases and developmental hypothyroidism. EC Nutrition 11.5: 183-185.

29. Ahmed RG (2017p) Maternofetal thyroid hormones and risk of diabetes. Int J of Res Studies in Medical and Health Sciences 2(10): 1821.

30. Ahmed R G(2017r) Association between hypothyroidism and renal dysfunctions. International Journal of Research Studies in Medical and Health Sciences 2(11): 1-4.

31. Ahmed R G (2017s) Maternal hypothyroidism and lung dysfunction. International Journal of Research Studies in Medical and Health Sciences 2(11): 8-11.

32. Ahmed R G (2017t) Endocrine disruptors; possible mechanisms for inducing developmental disorders. International journal of basic science in medicine (IJBSM) 2(4): 157-160
33. Ahmed R G $(2017 \mathrm{u})$ Maternal thyroid hormones trajectories and neonatal behavioral disorders. ARC Journal of Diabetes and Endocrinology 3(2):18-21.

34. Ahmed R G (2017v) Maternal thyroid dysfunction and neonatal cardiac disorders. Insights Biol Med 1: 092-096.

35. Ahmed RG (2018b) Maternal hypothyroidism and neonatal depression: Current perspective. International Journal of Research Studies in Zoology 4(1): 6-10.

36. Ahmed R G (2018c) Non-genomic actions of thyroid hormones during development. App Clin Pharmacol Toxicol: ACPT-108.

37. Ahmed R G (2018d) Maternal thyroid function and placental hemodynamics. ARC Journal of Animal and Veterinary Sciences 4(1): 9-13.

38. Ahmed R G (2018e) Interactions between thyroid and growth factors during development. ARC Journal of Diabetes and Endocrinology 4(1): $1-4$.

39. Ahmed R G (2018f) Maternal thyroid hormones and neonatal appetite. ARC Journal of Nutrition and Growth 4(1): 18-22.

40. Ahmed R G (2018g) Genomic actions of thyroid hormones during development. ARC Journal of Diabetes and Endocrinology 4(1): 5-8.

41. Ahmed R G (2018h) Dysfunction of maternal thyroid hormones and psychiatric symptoms. American Research Journal of Endocrinology 2(1): 1-6.

42. Ahmed RG (2018i) Is there a connection between maternal hypothyroidism and developing autism spectrum disorders? ARC Journal of Neuroscience 3(1): 5-8.

43. Ahmed R G (2018j) Maternal thyroid dysfunctions and neonatal bone maldevelopment. American Research Journal of Endocrinology (in press).

44. Ahmed R G (2018k) Maternal thyroid disorders and risk of neonatal seizure: Current perspective. ARC Journal of Neuroscience 3(1): 21-25.

45. Ahmed R G (2018l) Gestational dioxin acts as developing neuro endocrine-disruptor. EC Pharmacology and Toxicology 6.3: 96-100.

46. Ahmed R G (2018m) Maternal thyroid dysfunction and risk of neonatal stroke. ARC Journal of Animal and Veterinary Sciences 4(1):22-26.

47. Ahmed R G(2018n) Maternal thyroid disorders and developing skin dysfunctions. ARC Journal of Dermatology 3(1): 13-17.

48. Ahmed R G (2018o) Maternal hypothyroidism-milk ejections: What is the link? ARC Journal of Nutrition and Growth 4(1): 29-33.

49. Ahmed R G (2018p) Does maternal antepartum hypothyroidism cause fetal and neonatal hyponatremia? ARC Journal of Diabetes and Endocrinology 4(1), xx-xxx.

50. Ahmed R G (2018q) Maternal hypothyroidism and rheumatoid arthritis. International Journal of Research Studies in Medical and Health Sciences Volume 3(2): 1-5.

51. Ahmed R G (2018r) Developmental thyroid and skeletal muscle dysfunction. ARC Journal of Diabetes and Endocrinology 4(1), xx-xxx.

52. Ahmed R G, Incerpi S (2013) Gestational doxorubicin alters fetal thyroid-brain axis. Int J Dev Neurosci 31(2): 96-104.

53. Ahmed R G, Incerpi S, Ahmed F, Gaber A (2013b) The developmental and physiological interactions between free radicals and antioxidant: Effect of environmental pollutants. J of Natural Sci Res 3(13): 74-110.

54. Candelotti E, De Vito P, Ahmed RG, Luly P, Davis PJ, et al. (2015) Thyroid hormones crosstalk with growth factors: Old facts and new hypotheses. Immun Endoc \& Metab Agents in Med Chem 15(1): 71-85.

55. De Vito P, Candelotti E, Ahmed R G, Luly P, Davis P J, et al. (2015) Role of thyroid hormones in insulin resistance and diabetes. Immun Endoc \& Metab Agents in Med Chem 15: 86-93. 
56. El-bakry A M, El-Ghareeb AW, Ahmed RG (2010) Comparative study of the effects of experimentally-induced hypothyroidism and hyperthyroidism in some brain regions in albino rats. Int J Dev Neurosci 28(5): 371-389.

57. El-Ghareeb A A, El-Bakry A M, Ahmed RG, Gaber A (2016) Effects of zinc supplementation in neonatal hypothyroidism and cerebellar distortion induced by maternal carbimazole. Asian Journal of Applied Sciences 4(04): 1030-1040.

58. Fowden A L, Forhead A J (2009) Hormones as epigenetic signals in developmental programming. Exp Physiol 94(6): 607-625.

59. Forhead A J, Fowden A L (2014) Thyroid hormones in fetal growth and prepartum maturation. J Endocrinol 221(3): R87-R103.

60. Puig-Domingo M, Vila L (2013) The implications of iodine and its supplementation during pregnancy in fetal brain development. Current Clinical Pharmacology 8(2): 97-109.

61. Stenzel D, Huttner W B (2013) Role of maternal thyroid hormones in the developing neocortex and during human evolution. Frontiers in Neuroanatomy 7: 19.

62. ACOG Practice Bulletin (2001) Intrauterine growth restriction. Clinical management guidelines for obstetrician gynecologists. Int J Gynaecol Obstet 72(1): 85-96.

63. Conde-Agudelo A, Papageorghiou AT, Kennedy SH, Villarb J (2013) Novel biomarkers for predicting intrauterine growth restriction: a systematic review and meta-analysis. Int J of Obstetrics and Gynaecology 120(6): 681-694.

64. Tong Z, Xiaowen Z, Baomin C, Aihua L, Yingying Z, Weiping T, et al. The effect of subclinical maternal thyroid dysfunction and autoimmunity on intrauterine growth restriction. Medicine 95(19): e3677.

65. Fowden AL, Li J Forhead, AJ (1998) Glucocorticoids and the preparation for life after birth: are there long term consequences of the life insurance? Pro Nutr Soc 57(1): 113-122.

66. Hillman NH, Kallaour SG, Jobe A (2012) Physiology of transition from intrauterine to extrauterine life. Clin Perinatol 39(4): 769-783.

67. Sferruzzi-Perri AN, Vaughan OR, Forhead AJ, Fowden AL (2013) Hormonal and nutritional drivers of intrauterine growth. Curr Opin Clin Nutr Metab Care 16(3): 298-309.

68. Thorpe-Beeston JG, Nicolaides KH, Snijders RJ, Felton CV, McGregor AM (1999) Thyroid function in small for gestational age fetuses. Obstet Gynecolo 77(5): 701-706.

69. Kilby MD, Gittoes V N, Somerset D A, Clark P M, Franklyn J A (1998) Circulating thyroid hormone concentrations and placental thyroid hormone receptor expression in normal human pregnancy and pregnancy complicated by intrauterine growth restriction (IUGR). J Clin Endocrinol Metab 83(8): 2964-2971.

70. Rae MT, Rhind SM, Kyle CE, Miller DW, Brooks AN (2002) Maternal undernutrition alters triiodothyronine concentrations and pituitary response to GnRH in fetal sheep. J Endocrinol 173(3): 449-455.

71. Pereira D N, Procianoy R S (2003) Effect of perinatal asphyxia on thyroid stimulating hormone and thyroid hormone levels. Acta Paediatr 92(3): 339-345.

72. Piosik P A, van Groenigen M, van Doorn J, Baas F, Vijlder J J M (1997) Effects of maternal thyroid status on thyroid hormones and growth in congenitally hypothyroid goat fetuses during the second half of gestation. Endocrinology 138(1): 5-11.
73. Allen A L, Fretz P B, Card C E, Doige C E (1998) The effects of partial thyroidectomy on development of the equine fetus. Equine Vet J 30(1): 53-59.

74. Figueras F, Gardosi J (2011) Intrauterine growth restriction: new concepts in antenatal surveillance, diagnosis, and management. Am J Obstet Gynecol 204(4): 288-300.

75. Franco B, Laura F, Sara N, Salvatore G (2013) Thyroid function in small for gestational age newborns: a review. J Clin Res Pediatr Endocrinol 5(Suppl 1): 2-7.

76. Kady SM, Gardosi J (2004) Perinatal mortality and fetal growth restriction. Best Pract Res Clin Obstet Gynaecol 18(3): 397-410.

77. Barker D J (2006) Adult consequences of fetal growth restriction. Clin Obstet Gynecol 49(2): 270-283.

78. Pallotto E K, Kilbride H W (2006) Perinatal outcome and later implications of intrauterine growth restriction. Clin Obstet Gynecol 49(2): 257-269.

79. Leitner Y, Fattal-Valevski A, Geva R, Eshel R, Toledano-Alhadef H, et al. (2007) Neurodevelopmental outcome of children with intrauterine growth retardation: a longitudinal, 10-year prospective study. J Child Neurol 22(5): 580-587.

80. Varvarigou A A, 2010 Intrauterine growth restriction as a potential risk factor for disease onset in adulthood. J Pediatr Endocrinol Metab 23(3): 215-224.

81. Villar J, Carroli G, Wojdyla D, Abalos E, Giordano D, Ba'aqeel H, et al. (2006)Preeclampsia, gestational hypertension and intrauterine growth restriction, related or independent conditions? Am J Obstet Gynecol 194(4): 921-931.

82. Sharma D, Shastri S, Farahbakhsh N, Sharma P (2016) Intrauterine growth restriction - part 1. J Matern Fetal Neonatal Med 29(24): 39773987.

83. Fowden A L (2003) The insulin-like growth factors and feto-placental growth. Placenta 24(8-9): 803-812.

84. Incerpi S, Hsieh M T, Lin H Y, Cheng G Y, De Vito P, Fiore A M, et al (2014) Thyroid hormone inhibition in L6 myoblasts of IGF-I-mediated glucose uptake and proliferation: new roles for integrin $\alpha v \beta 3$. Am J Physiol Cell Physiol 307(2): C150-C161.

85. Kilby M D, Gittoes V N, Somerset D A, Clark P M, Franklyn J A(1998) Circulating thyroid hormone concentrations and placental thyroid hormone receptor expression in normal human pregnancy and pregnancy complicated by intrauterine growth restriction (IUGR). J Clin Endocrinol Metab 83(8): 2964-2971.

86. Piosik P A, van Groenigen M, van Doorn J, Baas F, Vijlder J J (1997) Effects of maternal thyroid status on thyroid hormones and growth in congenitally hypothyroid goat fetuses during the second half of gestation. Endocrinology 138(1): 5-11.

87. Stenzel D, Huttner WB (2013) Role of maternal thyroid hormones in the developing neocortex and during human evolution. Frontiers in Neuroanatomy $7: 19$.

88. Villar J, Carroli G, Wojdyla D, Abalos E, Giordano D, Ba'aqeel H, et al. (2006) Preeclampsia, gestational hypertension and intrauterine growth restriction, related or independent conditions? Am J Obstet Gynecol 194(4): 921-931. 

(c) (i) ${ }_{\text {Commons Attribution } 4.0 \text { License }}^{\text {This work is licensed under Creative }}$ BY
Your next submission with Juniper Publishers will reach you the below assets

- Quality Editorial service

- Swift Peer Review

- Reprints availability

- E-prints Service

- Manuscript Podcast for convenient understanding

- Global attainment for your research

- Manuscript accessibility in different formats

( Pdf, E-pub, Full Text, Audio)

- Unceasing customer service

Track the below URL for one-step submission https://juniperpublishers.com/online-submission.php 